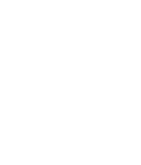

\section{REVIEWS Further}

Click here for quick links to Annual Reviews content online, including:

- Other articles in this volume

- Top cited articles

- Top downloaded articles

- Our comprehensive search

\title{
Does the Process of Constitution-Making Matter?
}

\author{
Tom Ginsburg, ${ }^{1}$ Zachary Elkins, ${ }^{2}$ and Justin Blount ${ }^{3}$ \\ ${ }^{1}$ University of Chicago Law School, Chicago, Illinois 60637; email: tginsburg@uchicago.edu \\ ${ }^{2}$ Department of Government, University of Texas, Austin, Texas 78712; \\ email: zelkins@austin.utexas.edu \\ ${ }^{3}$ Department of Political Science, University of Illinois, Urbana, Illinois 61801; \\ email: jblount2@uiuc.edu
}

Annu. Rev. Law Soc. Sci. 2009. 5:201-23

First published online as a Review in Advance on July 29, 2009

The Annual Review of Law and Social Science is online at lawsocsci.annualreviews.org

This article's doi:

10.1146/annurev.lawsocsci.4.110707.172247

Copyright (c) 2009 by Annual Reviews. All rights reserved

1550-3585/09/1201-0201\$20.00

\section{Key Words}

democracy, comparative politics, deliberation, institutional design, constitutions
Abstract
Constitution-making is a ubiquitous but poorly understood phe- nomenon. There is much speculation but relatively little evidence about the impact of different design processes on constitutional outcomes. Much of the debate reduces to the question of who is involved in the process and when. We consider two central issues in this regard. The first is the problem of institutional self-dealing, or whether governmen- tal organs that have something to gain from the constitutional outcome should be involved in the process. The second has to do with the mer- its of public involvement in the process. Both of these concerns have clear normative implications and both are amenable to straightforward social scientific analysis. This article surveys the relevant research on constitution-making, describes the conceptual issues involved in un- derstanding constitution-making, reviews the various claims regarding variation in constitution-making processes, and presents a set of base- line empirical results from a new set of data on the content and process of constitution-making. 


\section{INTRODUCTION}

Constitution-making is as ubiquitous as it is mysterious. In any given year, by our estimate, some 4 or 5 constitutions will be replaced, 10 to 15 will be amended, and another 20 or so proposals for revision will be under consideration (Elkins et al. 2009). These revisions represent potentially far-reaching changes to fundamental political rules. Yet our knowledge of constitutional (re)design processes and their consequences is cloudy at best. More than a decade after Elster (1995, 1997) lamented the dearth of theory on constitutional design (and, we would add, systematic empirical evidence), the field retains a frontier qualityexciting but unchartered-notwithstanding Elster's own valuable contributions. Many of us likely suspect that the conditions and rules under which founders write, deliberate, and ratify will be consequential. We just cannot say with any authority how they matter or to what extent.

At the same time, there is genuine reason for optimism about the prospects of improved knowledge. If the field is thin with respect to rigorous comparative research, it is becoming thicker and richer in case studies that can conceivably motivate researchers and shape theory. Founding moments are generally historical, if mythical, affairs, and historians have documented classic cases (e.g., Rakove 1997, Moore \& Robinson 2004, Golay 1958) in some depth. More recent cases have also been the subject of detailed accounts (e.g., Bannon 2007, Brandt 2005, Congleton 2003, Ghai et al. 2003, Goldwin \& Kaufman 1988, Haysom 2004, Hyden \& Venter 2001, Keogh \& McCarthy 2007, Moehler 2006, Rubin 2004, Selassie 2003; for an extensive bibliography of sources relating to post-1975 cases of constitutional design, see Widner 2005b). ${ }^{1}$ These accounts offer

\footnotetext{
${ }^{1}$ For a truly mythical take on both the process of constitutional design and political transition, see Murphy's (2007) account of a fictional constitutional convention in which the delegates intelligently engage scholars, experts, and themselves in discussions of both general principles and specific rules relating to the foundation of a democratic, constitutional state.
}

a rich source of inspiration for a literature whose needs are clear: conceptualization and measurement of the process, rigorous theorizing about the effects of different aspects of the process, and the testing of these theories with suitable empirical designs. More extensive comparative empirical work looms on the horizon, and we can expect steady growth, if not a boom in research on the topic (see Carey 2007; Samuels 2006; Widner 2005a, 2007a; Moehler 2007).

Our goals in this review are largely cartographic. We seek to chart the frontiers of our collective knowledge of constitutional drafting and adoption processes. Our particular focus is on the links between process and outcomes. We begin with a historical review of the literature and a description of different modes of constitutional design processes, including both the typical actors involved and the activities in which they are engaged. We then explore some of the microfoundational assumptions that undergird theory regarding the consequences of different processes; in particular, we address the motivations of participating actors. The bulk of the review is devoted to identifying hypotheses (or, more accurately, thoughtful conjecture) that appear in the literature on the relationship between these processes and various outcomes of interest. We describe existing evidence bearing on these hypotheses and suggest promising approaches to testing these claims further. Occasionally we draw on new cross-national data that we have at our disposal (Elkins \& Ginsburg 2007) in order to sketch some baseline associations. These analyses are meant not to be conclusive, but rather to serve as a point of departure for further research.

\section{LITERATURE ON CASES}

Constitutional compilations in the modern era have existed since at least 1783 when the French ministry of foreign affairs, at the request of Benjamin Franklin, authorized the publication of an anthology of U.S. state constitutions (Blaustein \& Sigler 1988). Early scholarly literature ( 1890-1945) on constitutions and constitutional design was largely case driven 
and responsive to new constitutional events. Not surprisingly, the end of World War I and the wave of new national constitutions that emerged in the breakup of empires spawned scholarly interest. These efforts were largely descriptive, in some cases going through new constitutional texts section by section (Davidson 1925, Pollock 1923) and in others simply providing a brief introduction to the constitutional text (Albert et al. 1894, Moses 1893). These early analyses are generally not concerned with process, but instead focus on describing institutions such as executivelegislative relations and regionalism (Dedek 1921, Quigley 1924). The issues of human rights (or, in the parlance of the time, the rights of man) and democratic theory are also raised in discussions of particular constitutional texts (Bentwich 1924, Clark 1921, Morse 1919).

There are exceptions to this general characteristic of atheoretical, institutional description, of course. Kantorowicz's (1927) examination of the Weimar Constitution is motivated by ascertaining the political goals of the designers and how well they met them by comparing the new republican constitution with the old imperial one. He also contrasts the operation of the constitution with its de jure provisions. Chapman (1925) attempts a similar undertaking in endeavoring to explain the disjunction between Cuba's Constitution and political reality (a culture of corruption, particularly in the Congress), ultimately concluding that the solution may be beyond the scope of any constitution.

Other works are more centrally focused on issues related to constitutional design processes such as legitimacy and the exercise of constituent power. Arangio-Ruiz (1895), for example, explicitly addresses the evolution of constituent power in Italy from 1848 onward. Although plans were made for an elected constituent assembly to establish a permanent constitution for Italy, they were never realized, and so the constituent function was never clearly assigned. This constitutional silence allowed parliament progressively to assume a constituent function. Perhaps motivated by institutional self-interest, Italian deputies and senators resisted calls for a constituent assembly. Likewise, they resisted the notion of a constituent power residing in the people, who were deemed incapable of exercising it. Arangio-Ruiz approvingly notes the objections of the parliamentarians that, given Italy's recent despotic past and lingering conservatism in the state bureaucracy and police services, locating constituent powers in the people would be a grave mistake.

Another historical work that speaks to contemporary themes is Currier's (1893) analysis of the circumstances surrounding the French Constitution of 1875 . As in the Italian case, constituent assembly elections scheduled for October 1870 were cancelled. The National Assembly elected the following February concluded peace with Germany and asserted implicit authorization to proceed with the drafting and adoption of a new constitution. Although the political and legal circumstances were muddied, the National Assembly was elected by universal suffrage and could justifiably claim to be a constituent body representing the "will of the nation and the sovereignty of the people" (p. 132). As Saleilles (1895) notes, however, such an action was out of line with previous French constitutional history. In an argument that anticipates Elster (2006), Saleilles maintains that the constituent, or sovereign, power cannot simultaneously lay in a constituted power such as a parliament.

Although single-country case studies have been and will continue to be an invaluable source of knowledge about specific episodes of constitutional design, recent decades have seen the emergence of volumes attempting to situate constitutional design process in a crossnational, comparative framework. Goldwin \& Kaufman (1988) is an invaluable example of this approach, involving a series of papers by contributors who are, with one exception, all former constitution writers themselves. The case studies provide insights into different aspects of the process to facilitate a better understanding of choices faced and decisions made as they worked to craft a new constitution for their respective countries. In a companion volume, 
Goldwin et al. (1989) replicate their previous task but with a specific focus on the issue of ethnic, linguistic, racial, and religious diversity. Banting \& Simeon (1985) highlight the political, rather than the legal or institutional, conflicts associated with constitutional change in select industrial countries.

More recently, both Reynolds (2002) and Hyden \& Venter (2001) have contributed edited volumes that address various aspects of constitutional design. Reynolds combines singlecountry case studies with thematic ruminations on institutional design to explore how much constitutions can reduce civil conflict and promote democratic governance. As noted below, the conflict resolution literature has provided much recent work on constitutional design, taking an instrumental approach.

Hyden \& Venter's analysis of constitutionmaking in four African countries is among the most theoretical and explicitly comparative studies in this vein. They construct a common theoretical framework and evaluate such constitutional design processes as the representativeness of the process, the mechanisms used to create the document and aggregate interests, and the extent of popular participation in the process. In a similar manner, Samuels's (2006) 12-country study commissioned by the Institute for Democracy and Electoral Assistance (IDEA) evaluated constitutional design processes on the dimensions of inclusiveness, representativeness, and popular participation, in part to determine the extent to which democratic design process can help generate democratic outcomes.

\section{CONSTITUTIONAL DESIGN: MODES, ACTORS, AND CONSTRAINTS}

Any particular instance of constitutional design must deal with certain basic questions of organization and process. These include designating who is to be involved; when that involvement takes place; and how the actors are to proceed in formulating, discussing, and approving a text. Although there are conceivably as many variants in the process as there are constitutions, several common patterns emerge.

Constitution-making occurs in discernible stages, some of which resemble an ordinary legislative process familiar to many drafters in consolidated democracies. Widner (2007b) has provided a useful schematic of design processes that should guide researchers and practitioners. She identifies the phases of constitutionmaking as drafting, consultation, deliberation, adoption, and ratification. Banting \& Simeon (1985) begin even earlier, focusing on the stage of mobilization of interests (and counterinterests) prior to the preparation of a text. They call this the "idea-generating stage" at which large parameters are laid out and the process itself may be determined.

These different stages interact with the possible actors who might fill the roles to create a matrix of options for designers. Afghanistan's Constitution of 2004, for example, was drafted in relative secrecy by a commission with foreign advice, then sent to the president's office before deliberation and adoption at an inclusive constituent assembly, the Loya Jirga (Huq 2009). In this model-which appears to be relatively common-each stage is potentially consequential, although it is likely that inertial forces and the power of agenda setting will apportion disproportionate influence to those actors involved at earlier stages. Still, it is quite possible that early-stage actors will anticipate the preferences and needs of later-stage actors, thus mitigating any sequence effects. Elster (1995, pp. 373-75) develops the vivid distinction between upstream and downstream constraints in the process: Upstream constraints are imposed by the powers setting up the constitutiondrafting body, whereas downstream constraints result from the anticipation of preferences of those involved in later stages. Ratification by public referendum, for example, is a downstream constraint that can hamstring leaders in an earlier stage who recognize that their document must ultimately obtain public approval.

As this discussion of constraints implies, a critical variable in constitution-making has 
Table 1 Actors and processes $(N=460)^{\mathrm{a}}$

\begin{tabular}{l|c|c}
\hline & Number & Frequency \\
\hline Constituent assembly & 53 & $12 \%$ \\
\hline Constituent legislating assembly & 15 & $3 \%$ \\
\hline Constituent legislature & 89 & $19 \%$ \\
\hline Executive & 40 & $9 \%$ \\
\hline Referendum & 6 & $1 \%$ \\
\hline Constituent assembly + executive & 42 & $9 \%$ \\
\hline Constituent assembly + legislature & 0 & $0 \%$ \\
\hline Constituent assembly + referendum & 13 & $3 \%$ \\
\hline Constituent legislating assembly + executive & 9 & $2 \%$ \\
\hline Constituent legislating assembly + referendum & 2 & $<1 \%$ \\
\hline Constituent legislature + executive & 78 & $17 \%$ \\
\hline Constituent legislature + referendum & 9 & $1 \%$ \\
\hline Referendum + executive & 57 & $12 \%$ \\
\hline Constituent assembly + executive + legislature & 4 & $<1 \%$ \\
\hline Constituent assembly + executive + referendum & 3 & $<1 \%$ \\
\hline Constituent assembly + legislature + referendum & 1 & $<1 \%$ \\
\hline Constituent legislature + executive + referendum & 16 & $4 \%$ \\
\hline Constituent assembly + executive + legislature + referendum & 1 & $<1 \%$ \\
\hline Other & 22 & $5 \%$ \\
\hline
\end{tabular}

${ }^{a}$ Coding rules are described in an online appendix at http://www.comparativeconstitutionsproject.org.

to do with which actors are included in the process. Institutional scholars are used to thinking of actors as "veto players" (Tsebelis 2002), and the constitutional design realm is no different. As Widner (2007b) describes, actors involved in constitution-making can include expert commissions, legislative bodies or committees, the executive, the judiciary, national conferences, elite roundtables, transitional legislatures, specially elected constituent assemblies, interest groups and nongovernmental organizations, foreign advisors, and the public itself. Public involvement, discussed further below, has become the subject of particular attention in recent years and is urged by scholars, governments, and international organizations (Ebrahim et al. 1999, Samuels 2006, Elkins et al. 2008a, Banks 2008). But not all constitutions involve the public, and some are drafted by a handful of leaders behind closed doors.

To sketch some patterns of actor involvement, we have gathered data on the process of adoption for 460 of the 806 national constitutions promulgated in the period 1789 2005. [In a larger project-the Comparative Constitutions Project (CCP)—we are engaged in the collection of data on the content of all 806 constitutions. See Elkins \& Ginsburg (2007).] The information on process reveals a pattern of constrained variation in the choice of actors. The principal actors include constituent assemblies, executives, ordinary legislatures, and the public through ratification referenda. At least one of these actors is formally included in $95 \%$ of the design processes in the sample. ${ }^{2}$ As Table 1 reveals, however, there is some variation in how different design processes

\footnotetext{
${ }^{2}$ The 22 cases that do not fit this categorization are generally either former UK colonies whose independence constitutions were negotiated at elite-level constitutional conferences and passed as Parliamentary Acts in London with the Queen's formal consent or represent cases of adoption/ratification by subnational legislatures or federal units such as BosniaHerzegovina in 1995 and Germany in 1871. The United States is classified as a constituent assembly-centered process.
} 
utilize the actors. Just less than one-half of processes utilize a single actor.

This accounting does not reveal anything about the depth or quality of involvement. Executives, for example, were involved in some manner in $51 \%$ of processes we analyzed. In some cases, however, executive involvement may have been merely formal, such as acting as the last official to sign the constitution, whereas in other cases it may have been more substantial. ${ }^{3}$ For some analyses, it is useful to identify the institution, or actor, with the most influential role in shaping the document (Elster 2006). We engage in this sort of categorization when we turn to some preliminary analysis of questions of self-dealing (below).

Certainly, a central dimension on which constitution-making processes differ is the degree of public participation. Because the constitution is the highest level of lawmaking and provides the ultimate rule of recognition for lawmaking processes (Kelsen 1945 [1961], Hart 1961), it requires the greatest possible level of legitimation in democratic theory. In an ideal world, one would desire universal consent over

\footnotetext{
${ }^{3}$ We adopted special coding rules vis-à-vis the executive role in constitutional design processes for two subtypes of authoritarian regimes. Adoption by a political party in a civilian dictatorship was judged equivalent to the role of an executive in the design process. Two texts were classified by this rule. By Article 73, the Mozambique Constitution of 1975 was "[a]pproved by acclamation by the Central Committee of the Mozambique Liberation Front on 20 June 1975." The second case was the Burma Socialist Programme Party-created Myanmar Constitution of 1974 that was eventually approved by referendum. In both cases, the party or party organs are interpreted as executive in nature, leading to classifications of executive and referendum-executive design processes. Military regimes (which make up 92 out of 291 cases for which regime type is available) are an additional special case of executive action. The modal design process choice for such regimes is the referendum-executive model, with 36 constitutions coming into force in this manner. Overall, 47 of the 92 constitutions adopted and promulgated by military regimes held ratification referenda. In contrast, there are only 10 instances of executive-only design processes. In 11 cases, ratification referenda were held by military regimes with no additional information provided about other actors. On the assumption that the leadership is clearly a gatekeeper of the referenda process in such regimes, these processes were categorized as involving executive action.
}

the rules of society, a standard that is obviously impractical (Buchanan \& Tullock 1962). Our sense is that actual constitutional design processes employ scattered and usually rather anemic forms of popular participation and oversight to substitute for actual consent. Higher levels of participation are presumed to function like supermajority rules, restricting the adoption of undesirable institutions and protecting prospective minorities in the democratic processes that are established. Participation thus legitimates and constrains, substituting inclusive processes for consent to make effective government possible.

The modal form of participation in constitutional design is the power to approve the charter, usually by referendum on the final document as a whole. Figures 1 and 2 present historical data on the processes of promulgating constitutions and on public promulgation in particular. Figure $\mathbf{1}$ plots the percentage of constitutions in force, by year, whose text requires public ratification. The plot suggests a significant trend, beginning in the early twentieth century, toward public ratification. We emphasize that the denominator here includes only those constitutions that specify any promulgation procedure in the text itself, including executive signature, legislative approval, or public ratification. As Figure 2 attests, although most modern constitutional texts provide information on promulgation, most nineteenth century texts were silent on the topic. We thus treat the findings in Figure 1 with some caution, although the shift in norms regarding the appearance of promulgation procedures in the text is unlikely to bias the results significantly. Indeed, our review of extratextual case information for a smaller sample suggests that the trend implied by the cases plotted in Figure $\mathbf{1}$ is fairly representative of the trend within the full sample of cases. Thus, public ratification has likely been on the rise since the turn of the twentieth century.

Approval by referendum may be an increasingly popular mode of public involvement, but it is clearly a limited one in that it involves 


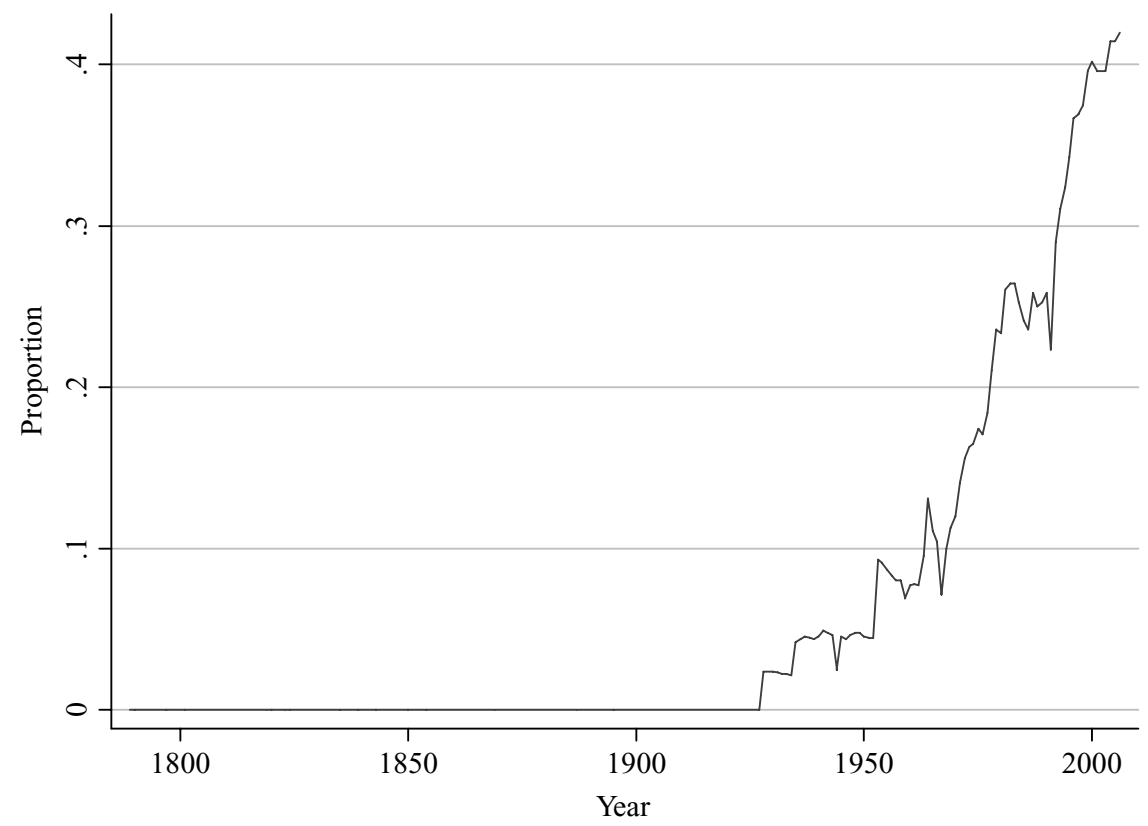

Figure 1

Proportion of constitutions in force that specifically require public ratification. Note that the universe is national constitutions that specify any promulgation procedure, such as by executive signature, legislative approval, or public ratification.

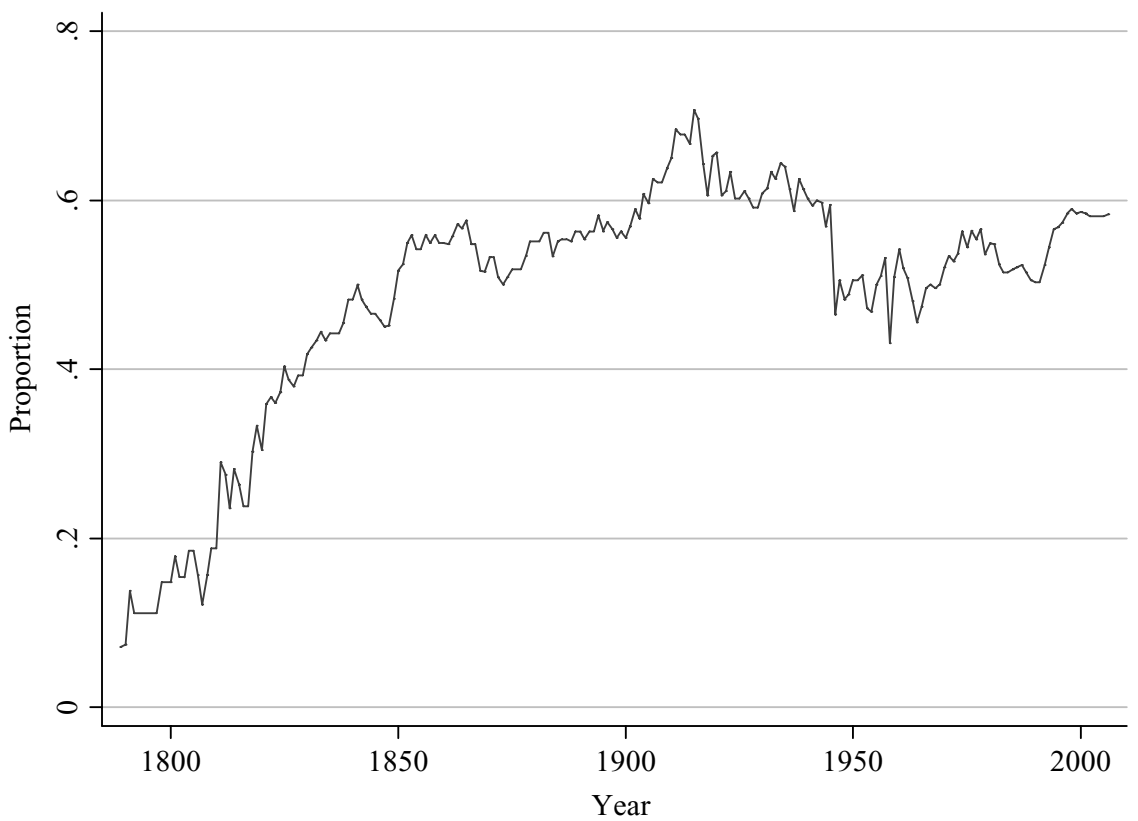

Figure 2

Proportion of constitutions in force that specify some promulgation procedure (public or otherwise). 
only an up or down vote over a package of provisions. ${ }^{4}$ Since at least World War II, however, participation in constitutional design has become more direct and has penetrated more deeply (or at least earlier) in the process. One common approach is to involve the public in selecting those who will draft or deliberate over aspects of the charter (Widner 2005a, pp. 78). This sort of voice is possible whether the representative group is a constituent assembly elected expressly for the purpose or is a regular legislature that takes on the project in addition to other duties. Some constitutional processes have experimented with more bottom-up methods of direct democracy, such as the citizen initiative, in which ideas can bubble up from civil society. We cannot say much yet about the effect of such methods, although anecdotal accounts, such as the report that citizens submitted 64,000 proposals to the Brazilian 1987-1988 assembly (Benomar 2004), suggest the magnitude of the challenges involved in absorbing public suggestions.

Still another mode of participation involves direct consultation with the public or representative groups at various stages, which might occur before, during, or after the drafting of the initial text (Ghai 2004, Ghai \& Galli 2006, Samuels 2006, Widner 2007a, Selassie 2003). The drafting phase seems to be especially crucial because we can expect a fair degree of inertia in the later stages of the process. But the phase is also likely to be the least participatory, given the challenges of writing-by-committee, much less writing-by-nation. Indeed, in some well-known cases, the public is excluded from the drafting process and not consulted at all.

Of course, actors and their accompanying constraints may come from outside, as well as inside, a state's borders. An extreme case is that of the "occupation constitution" (Elkins et al. 2008b; see also Feldman 2005), a document

\footnotetext{
${ }^{4}$ Interestingly, the 1978 Ecuadorian referendum held by the military government provided for a choice of constitutions. A "yes" vote indicated support for the newly drafted text, whereas a "no" vote indicated support for the previously abrogated 1945 Constitution.
}

drafted when a country is under the control of a foreign military power. Such constitutions are usually presumed to have less involvement on the part of local actors and hence to be less legitimate. Burnell (2008) believes that international involvement creates disincentives to enforce the constitution locally, as actors will strategically acquiesce to conditions they have no intention of fulfilling simply to remove external oversight. He cites Zimbabwe and the Lancaster House Agreement of 1979 as a prime example of this kind of behavior.

The voluminous literature on policy diffusion reminds us that policy reform is a highly interdependent process. Constitution-makingoften undertaken during moments of crisis when states are at their most amenable to foreign models and suggestions-may be especially interdependent and networked (Elkins 2009). Certainly, scholars have long noted a high degree of similarity across documents, and nearly anyone privy to the details of a case of constitution-making can recount an episode of international borrowing. John Meyer and other sociologists working within the "world society" perspective point to constitutional isomorphism as case in point in their compelling globalization narratives (Meyer et al. 1987, Go 2003). The persistence of presidentialism in Latin America, the use of French and Westminster models of government in former colonies, and the recent use of national conferences in Francophone Africa (Clark 1994) are all examples of diffusion that occurs at a subglobal level.

Given the persistent centrality of the U.S. Constitution to the American legal academy, there has been a fair amount of interest in documenting the influence of the U.S. Constitution over the years (e.g., Billias 1990), but other constitutional models have also had some impact (Elkins 2003). In public law, much of this research has found its way into a series of compilations of work on constitutional borrowing, which cover a decidedly heterogeneous set of transnational issues involving both constitutional design and interpretation [see, for example, Choudhry 2006 and special issues 
on the subject in the International fournal of Constitutional Law (Friedman \& Saunders 2003) and the Texas Law Review (2004)].

Of course, international constraints on constitution-making can range in their intensity and degree of coordination, from borrowing to imposition. External influence need not be as blatant as in occupation constitutions. Constitutional drafting that occurs concurrently with peace negotiations often attracts international advisers and interests, be they donors, creditors, interested states, or the UN. Samuels \& Wyeth (2006) briefly discuss the sometimes unintended but nonetheless negative consequences of such benign intervention. Also, some models exhibit pull-through proximity: The prospect of future membership in the European Union, for example, led some Eastern European countries to make modifications to their draft constitutions at the behest of the Council of Europe (Elster 1997, p. 129). Many accounts of foreign borrowing point to the decisive role of influential consultants (e.g., Davis 2003), and several scholars have sought to profile these consultants and describe their behavior (Perry 1992).

There are other potentially consequential aspects of process apart from the identity of the actors involved. Some constraints reflect the circumstances that lead to constitution-making in the first place. The conventional wisdom is that constitution-making is coincident with a cataclysmic event of some kind, such as war, coup, economic crisis, or revolution (Russell 1993, Elster 1995). In fact, the evidence suggests that, although crises do frequently precede constitutional reform, the degree of noncrisis constitution-making is probably underestimated (Elkins et al. 2009). ${ }^{5}$ Sweden's 1972 reform of its 163-year-old constitution is a prominent example of crisis-free reform (Congleton 2003). The various socialist constitutions, such as those in the Soviet Union (1936,

\footnotetext{
${ }^{5}$ Approximately half of new constitutions in our sample are promulgated within three years of a military conflict, economic or domestic crisis, regime change, territorial change, or coup (Elkins et al. 2009).
}

1977) and China (1982), seem to follow the installation of new leaders, a practice that was often justified by the Marxist view of evolution in stages (see Go 2003). These different patterns, reflecting various degrees of crisis or continuity, will affect the process, creating either an atmosphere of urgency or of deliberation.

The process can also vary in terms of time involved. At one extreme, the secretive process that led to Myanmar's 2008 Constitution took 17 years. $^{6}$ At the other extreme, a small group of American bureaucrats working for the occupation authorities drafted the basic form of Japan's 1946 Constitution in a little over a week, and the entire process, including elections, legislative deliberation, and approval by the emperor, took a mere eight months (Moore \& Robinson 2004). Which of these cases is closer to the mean? Japan, it seems, by a long shot. We randomly sampled 150 of the 806 cases of constitution-making (new and replacement constitutions) since 1789 and were able to identify the start and end dates for the processes in 148 of those cases. ${ }^{7}$ On average, constitutionmaking took 16 months in those 148 cases, with a standard deviation of 22 months. The median process length of the surveyed cases was 10 months.

Anecdotally, those constitution-making processes involving either a very short or very long amount of time seem to occur in nondemocracies. Speedy processes do not allow sufficient time for mobilization of the public

\footnotetext{
${ }^{6}$ One of the ironies of the long-awaited Burmese Constitution is that the military government insisted that the referendum on the document continue as scheduled during one of worst natural disasters in the country's history; this after years of delay in the drafting!

${ }^{7}$ Starting dates were identified in one of six ways, in decreasing order of priority: official announcement of intention to draft a new constitution including statements as to the identity of the drafting or adopting body; date of elections to the drafting and/or adopting body, if relevant; date of first meeting of the drafting and/or adopting body; date of formation of drafting subcommittees in either constituent assemblies or legislatures; for Commonwealth countries, the opening day of the first constitutional conference prior to independence; date of successful coup d'état. Ending dates reflect day of promulgation or, if unavailable, the date of final approval.
} 
and civil society, whereas extended processes are unlikely to hold public attention for the duration. The record for shortest process, formally at least, may belong to the Romanian Constitution of 1938, which instituted a brief period of royal dictatorship. A new cabinet taking power on February 12 of that year announced its intention to appoint a commission to draft a new constitution. A new text was published on February 21, a referendum conducted using oral voting under a state of siege was held on February 24, and promulgation by the king occurred three days later. Similarly, Napoleon's take on constitutionalism, the French constitution of 1799 , was launched a little more than a month after his coup on 18 Brumaire of Year VIII (November 9). These were expeditious processes, to say the least.

Another dimension on which processes differ is the size of the deliberative body. Bannon (2007) argues that the Kenyan constitutional design process was too bloated, with more than 600 delegates and two bodies producing drafts. Textual coherence and internal consistency appear to have been casualties of the process. Even Yash Ghai, the former chairperson of the Review Commission of Kenya, noted that Uganda and South Africa managed the process with 300 delegates (Onyango 2004). To mitigate this problem in the future, Bannon (2007) recommends a smaller deliberative body with a greater focus on public consultation at the expense of extensive representation of all interests.

Recent studies have also begun to examine the institutional structure of constituent bodies. Generalizing models from the area of legislative studies, Proksch (2007) and Tsebelis \& Proksch (2007) find evidence in the European Union Constitutional Convention of agendasetting power on the part of both the convention's praesidium and the subcommittees. One implication of this is that representative, inclusive constituent bodies may not be a sufficient condition for representative, inclusive texts if the possibility exists for biased committees. In effect, the level of analysis most commonly applied to design processes may be misleading. Continued systematic examination of the inner workings of constituent bodies and application of social science analytic methods to their proceedings hold the promise of leading to a better understanding of how particular provisions make their way into a text and of how participation is channeled.

In sum, processes of constitutional design and adoption vary widely along many dimensions. There is much speculation but relatively little evidence about the impact of these processes on different outcomes. The remainder of this review considers the range of hypotheses regarding this impact and the available evidence.

\section{CONNECTING PROCESS AND OUTCOME: MICROFOUNDATIONAL ASSUMPTIONS}

Assumptions about the motives of those participating in the process, be they elites or citizens, are central to hypotheses about the relation between process and constitutional outcomes. Nearly all the normative and positive work on constitutions proceeds from the assumption that constitutional politics are fundamentally different in character from ordinary politics. This is a central assumption of constitutional political economy (Buchanan \& Tullock 1962) but also of much other thinking about constitutions and constitutionalism (Ackerman 1993). The basic idea is that legal or political entrenchment distinguishes choice about rules from choice within rules. Because constitutional designers operate without certain knowledge of their prospective position in postconstitutional governance, they are presumed to pay greater attention to the public rather than to the private interest. Furthermore, it is argued, constitutions are typically adopted during moments of crisis and so are more likely to produce attention to the general welfare and less likely to be dominated by special interests.

Assumptions about motive also inform normative work on constitutional design processes. On the one hand, if one believes designers will act in their own self-interest, one might want to 
ensure maximum participation in the process to counter this tendency. On the other hand, if one believes that designers can take the public interest into account, one might design a process with more limited public involvement so as to facilitate elite deliberation.

Elster (1995) postulates three types of motivations that necessarily are balanced in the constitutional design process: reason, passions, and interests. Reason represents disinterested principles; passions refers to emotional factors such as religious or ethnic animosities or sudden, impulsive desires; and interests refers to those motives identified with the welfare of drafters or with broader groups or institutions of which they are a part. Elster believes that balance is necessary: A constitution that is too crudely identified with self-interest may fail to be adopted, as might one that is perfect in theory but fails to meet key needs of certain players (see also Ghai 2005). Elster (1997, p. 130) concludes that direct self-interest of the framers is less important than the interests of their constituents, but he also finds (Elster 1996) that institutional interests dominated in Eastern European constitution-making.

In a recent article, Brown (2008) modifies some of Elster's claims. Noting that in the best of worlds there is a certain amount of unpredictability in the process, Brown (2008) argues for the notion of "passionate rationality." In his conception, actors seek to pursue ends efficiently, but they do not always recognize what these ends are, much less how to pursue them. As a result, miscalculation and unintended consequences may loom large in constitutional design (Smith \& Remington 2001). Elster (2006) provides several examples of miscalculation and its consequences: the decision by Louis XVI to allow parish priests rather than bishops to represent the clergy in the Estates General; the adoption of proportional voting by the Weimar Assembly in 1919 despite the fact that it was against the interests of the socialist government to do so; and Vaclav Havel's insistence on proportional voting that allowed Communists into the Constituent Assembly, where they became "constitution wreckers rather than...constitution makers" (Elster 2006, p. 189). Scheppele (2008) echoes this point in cautioning that the crucial variables for constitutional success are beyond the ability of designers to control, and so "constitutional luck" plays an important role in the ultimate success or failure of constitutional arrangements.

Assumptions regarding the motives of actors undergird expectations about how process affects outcomes. In large part, these assumptions lead scholars to focus on the negotiators and drafters, with the idea that the identity of the constitution's authors will go far to explain its content. Constitutions, of course, may not simply be the sum of the interests of those involved; it is likely, for example, that decision rules and other conditions will also prove consequential. Nonetheless, strong theory and predictions regarding the "who" of the constitutional process is a good place to start.

\section{HYPOTHESES AND EVIDENCE LINKING PROCESSES TO OUTCOMES}

In this section, we identify a set of hypotheses regarding process and outcome and summarize the available evidence. Our focus, in particular, is on expectations regarding the interests and influence of institutional loyalists, international actors, and the public, all of whom are thought to play an increasingly consequential role in constitutional design.

\section{Institutional Self-Dealing}

It is common to think of constitutions as products of various competing interest groups organized along economic goals, ethnic claims, or political ideology. ${ }^{8}$ It also seems plausible

\footnotetext{
${ }^{8}$ Following Beard's (1913) classic argument, for example, McGuire \& Ohsfeldt (1986, 1989a,b) use statistical analysis to evaluate the voting behavior of the delegates to the U.S. Constitutional Convention and subsequent state ratification processes, and they find some support for public choice hypotheses of economic self-interest among participants.
} 
that drafters who occupy or seek to occupy government positions may act in the interest of their respective institutions. Once we consider this possibility, the institutional identity of actors in the design process becomes paramount. One theme in the literature is suspicion of legislators as constitution-makers. As we describe above, the legislative model of constitutional design involves electing a legislature to accomplish both ordinary and constitutional rule-making, so that choices about constitutional design are bundled with the concerns of ordinary law. One problem with this bundling concerns interest aggregation: The voter's constitutional preferences may be traded off against other concerns in choosing a representative. The qualities that make a legislator attractive to a voter (e.g., attention to local interests) may not be what that voter would look for in a founding father or mother. More centrally, however, there is a reasonable suspicion that legislators will aggrandize their own institution in designing a governance structure. The solution is to bypass the legislature. As summarized by Elster (1995, p. 117): "To reduce the scope for institutional interest, constitutions ought to be written by specially convened assemblies and not by bodies that also serve as ordinary legislatures. Nor should legislators be given a central place in ratification."

The skepticism regarding institutional self-interest is certainly not limited to sitting legislatures. The critiques of legislativecentered processes would presumably be even more scathing for constitutions drafted in executive-centered processes, given the distrust of heavy-handed executive rule in democratic governance. Indeed, it is hard to imagine that a constitution such as that recently produced in Myanmar, ruled by a military junta that handpicked the drafters and the deliberative body, would undercut executive power. In another example, the Armed Forces Ruling Council in Nigeria, which reserved for itself a decisive editing role at the end of the constitutional process, rejected a provision drafted by the Constituent Assembly that would have made coup participants punishable at law (Ehindero 1991). A general expectation of institutional self-dealing means that we ought to expect that executive-centered processes will lead to stronger executives in the resulting constitution.

The evidence of institutional self-dealing is largely anecdotal (Elster 1996, Ghai 2005, Ghai \& Galli 2006, Samuels 2006). Drawing on our own cross-national data on the content of constitutions, we provide here some preliminary findings on these questions intended only to provoke further inquiry and certainly not to settle the questions. Recall our sample of 460 constitutions for which we had gathered information on the identity of actors involved in each of the processes. We can categorize these processes, following Elster (2006), as either executive-centered, constituent assembly, constituent legislating assemblies, constituent legislatures, or a residual category for other cases. The labels can be confusing, but the institutions are straightforward. The principal contrast is between constituent assemblies, which are elected especially to design a constitution and then disband, and constituent legislatures, which are legislatures that take on the added task of constitution-making. The constituent legislating assembly refers to an intermediate category of cases in which assemblies elected specially for constitutional design transform themselves into a sitting legislature. Executivecentered processes include those adopted solely by an executive or adopted by an executive and approved through referendum. We were able to categorize 411 of our 460 cases without difficulty according to these four categories, leaving 49 in the "other" category.

We next drew on our own data from the CCP to create an index of legislative power, based on a parallel set of items from Fish \& Kroenig's (2009) Parliamentary Powers Index (see also Fish 2006). Fish \& Kroenig aggregate 32 dimensions of legislative power, equally weighted, into an index representing the level of legislative power in a constitutional system. Their measure, which relies upon expert codings, is a de facto measure of legislative power, whereas our parallel measure is a de jure 
measure based on the formal provisions of the text. We employ a set of variables from the CCP that map onto 21 of Fish \& Kroenig's items and score cases a 1 for each provision present in the constitution. We then calculate the mean of these 21 binary variables, resulting in an index that ranges between 0 and 1, with 1 representing the maximum amount of legislative power. If the hypothesis of institutional self-interest has merit, we would expect that legislativecentered processes would feature stronger legislatures than would constituent assemblycentered processes, whereas executive-centered processes would feature weaker legislatures than either. Table 2 provides the mean value of our de jure measure of parliamentary power as provided in the constitutions produced by each of the four process categories.

Interestingly, we find no bivariate support for the hypothesis that legislatures produce constitutions with more parliamentary power than do constituent assemblies: The mean value for the parliamentary power index for cases of constituent assembly is actually higher than that of those centered in the legislature, although difference of means tests do not meet standard levels of significance. Executive-centered processes, on the other hand, yield significantly less power for legislatures than do processes in the other two categories (a $t$-test indicates that the difference in means is significant at the 0.01 level). Elster's conjecture about institutional self-interest, it seems, is evident only with regard to executive-centered processes.

This finding that constituent assemblies are more likely to empower the legislature than are the legislatures themselves is striking. Of course, the finding could still reflect institutional self-dealing in that members of a constituent assembly foresee themselves inhabiting the legislature at some point in the future, even if that career path is not guaranteed. The finding could also reflect the possibility that members of a constituent body-sitting and reflecting as a representative group-are philosophically and politically inclined toward representative government, as opposed to a more hierarchical form that they would identify with
Table 2 Constitutional design processes and average de jure parliamentary power

\begin{tabular}{l|c|c}
\hline & Number & $\begin{array}{c}\text { Mean level of de jure } \\
\text { parliamentary power }\end{array}$ \\
\hline Constituent assembly-centered & 103 & 0.38 \\
\hline $\begin{array}{l}\text { Constituent legislating } \\
\text { assembly-centered }\end{array}$ & 26 & 0.41 \\
\hline Constituent legislature-centered & 178 & 0.37 \\
\hline Executive-centered & 84 & 0.30 \\
\hline Other & 20 & 0.20 \\
\hline
\end{tabular}

executive power. Finally, the bivariate association could be the product of any number of confounds or statistical artifacts. One obvious confound is time. Our sample includes cases dating to the early nineteenth century. To the extent that constitutional processes and legislative power both covary with time, we may be capturing a simultaneous, but unrelated, pair of trends. However, if we detrend the data (by running a simple regression with year as a covariate), the results remain: Constituent assembly products are indistinguishable from legislativecentered texts with respect to legislative power, but both texts provide significantly more legislative power than do texts written in executivecentered processes (we regressed the legislative power index on year and dummy variables for legislature-centered processes and constituent assembly processes, with executive processes as the residual category).

Still, this analysis is plagued by another methodological concern that affects nearly all empirical work on process and outcome: endogeneity. In this case, a state's predisposition toward strong legislatures might influence both their formal constitutional text and the process they use to produce the text. This sort of endogeneity, however, should produce a bias toward a positive association between legislative power in the text and legislature-centered processes. Given the direction of this bias and our finding of no difference between constituent assembly and legislature processes, we have rather strong exculpatory evidence that legislatures are not guilty of self-dealing. Nonetheless, our results here represent simply an initial baseline 
finding; deeper exploration of this relationship is certainly warranted.

\section{International Actors}

The role of international actors in constitutionmaking is varied, and so too are the empirical expectations. One basic expectation is that outside actors will export constitutional provisions from their home country. This presumption seems most likely in situations in which the sovereignty of the host country is compromised, such as in the case of occupation. The assumption is that constitutions drafted under the watchful eye of an occupying power will involve the more or less forcible transfer of institutions from the occupier to the occupied. Even if not motivated by self-interest on the part of the occupying power, one might expect a certain amount of institutional propagation to take place if only through the occupier's institutional habits or even deferential mimicry on the part of the occupied. Through a number of complementary mechanisms, therefore, we should expect that such constitutions bear some similarity to the occupying powers. It may be, however, that the coercive relationship between occupier and occupied plays out in more subtle ways with respect to constitutional design. Failing outright adoption of the occupier's institutions, at the very least the occupier's presence may disrupt the host country's normal search process for relevant constitutional models (Elkins et al. 2008b).

Of course, military occupations represent an extreme case, and international actors may be influential even in less coercive situations. States are enmeshed in any number of international networks that render the experiences and constitutions of certain countries more relevant than others.

Occupation and other sorts of international processes may also have strong effects on the fit and functionality of constitutional provisions. Elkins (2003,2009) has sought to uncover these sorts of social welfare effects with respect to constitutional diffusion. At the extremes, we see two plausible, but divergent, effects. External participation may lead drafters to adopt suboptimal or inappropriate provisions designed for the needs of others. Alternatively, outsiders may lead drafters to adopt provisions superior to those that drafters have the resources or knowledge to engineer for themselves. These effects will likely vary according to the kind and extent of external participation and the conditions under which it occurs.

The evidence for these sorts of international hypotheses is growing steadily owing to a noticeable increase in scholarly interest in transnational mechanisms of institutional reform. With respect to the hypotheses regarding military occupation—specifically regarding endurance and imposition - we can report findings from Elkins et al. (2008b), who survey 42 instances of constitutions adopted under occupation or shortly thereafter and develop an index of similarity to compare constitutional dyads. They find that, on average, occupation constitutions are moderately more similar to those of the principal occupying nation. With regard to two prominent constitutions drafted under U.S. occupations, for example, they find some similarity between the U.S. Constitution and that of Japan in 1946, but find very little with respect to the Iraqi Constitution of 2005. Although they find that occupation constitutions are less enduring than other constitutions, this result does not hold in a multivariate specification (Elkins et al. 2009).

\section{Public Participation and Oversight}

Elster (1997, p. 125) generalizes that constitutions produced in more democratic processes will tend to be more democratic. Given the recent trend toward participation in constitutional design, it is worth inquiring how constitutions produced through participatory processes may be systematically different from other constitutions. A small literature nested in the larger trove of work on political participation more generally has generated a host of hypotheses.

First, participatory constitutional design processes may undermine textual coherence 
(Voigt 2003). As Horowitz (2002) notes, even under the best of circumstances, constitutional design - a term he reserves for a cohesive process-is quite rare, with some process of incremental construction more the norm. Constitution-making frequently consists of a combination of institutional borrowing, wholesale grafting, logrolling, and improvisation. As new and more actors become involved in the process, bargaining and negotiation become both more extensive and more intensive. In addition, the populace may be subject to cascades that exacerbate the element of passion in constitutional design (Elster 1995). The constitution that emerges from this process will almost certainly be an ad-hoc creation, rife with internal inconsistencies and institutional mismatches. Although the loss of design consistency may be offset by resultant gains in legitimacy (Horowitz 2002), it may also render the constitutional scheme unworkable. Additionally, simply increasing the number of actors is no guarantee of a more equitable outcome. The composition of a deliberative body is as important to the ultimate outcome as the number of members; extreme outcomes can emerge from a collective decision-making process (Sunstein 2001, chapter 1). A related point is that participation may also lead to more specific and detailed constitutional documents (Elkins et al. 2009). Analogizing to the contracts literature, more diverse parties are likely to want to specify their bargain in greater detail because of distrust of counterparties and concerns about strategic nondisclosure of preferences during the bargaining process. Thailand's 1997 document, for example, was designed to limit political institutions by setting up a large number of watchdogs, all elaborated in excruciating detail in the constitution. Similarly, if the public perceives opportunities for participation to be episodic, it may seek to constitutionalize various institutions that would ordinarily be left to nonconstitutional politics. For example, Brazil's 1988 process was a model of public participation involving citizen proposals on content. The resulting document is one of the world's longest, at over 40,000 words.
We know of no empirical study that has systematically analyzed constitutions for coherence or related concepts. That constitutions contain a complex array of institutions certainly poses a challenge to research design. Undoubtedly, one can find examples of poor drafting, internal contradictions, or errors, but no one has yet tied these directly to participation. Crossnational approaches might focus on issues of constitutional length and scope, either of which might be construed as indicators of specificity or even incoherence. Even then, it seems likely that these sorts of questions are best suited to case-oriented research.

A different line of critique emphasizes the difficulty of reaching agreement. More actors will, ceteris paribus, increase the transaction costs of negotiation, particularly when participants have veto powers over the adoption of new rules (Tsebelis 2002). A more open process can also make bargaining and the granting of concessions more difficult (Arato 1995, Elster 1995, Sunstein 2001). This is in part because the drafters will feel the need to signal positions to their constituents outside the process, potentially leading to more extreme positions. The drafters may also be interested in using the bargaining process to grandstand, decreasing the possibility of agreement. Open processes of negotiation will tend to hinder tough choices and compromise. This suggests that participatory processes are less likely to produce a constitution, although arguably the documents that do emerge will be more legitimate.

The claim that participatory design processes generate constitutions with higher levels of legitimacy and popular support has been subject to only limited study. We can find case studies that seem to support both the more optimistic and more pessimistic hypotheses. South Africa is rightly celebrated as a case in which participation was extensive, and the resulting document scores well on measures of rights, endurance, and enforcement. In contrast, Eritrea, Ethiopia, and Thailand used broadly participatory processes that had little to no effect on the subsequent political system (Ghai \& Galli 2006, Selassie 2003). Thailand's 1997 process 
included a provision disallowing constitutional drafters from running for postconstitutional office for a period, a suggestion approved by the theoretical literature (Voigt 2003, p. 217), but this did not prevent electoral corruption from reviving. In fact, Thailand's participatory process appears not to have built a reservoir of support for the constitution, which died in a coup in 2006 without much ado (Kuhonta 2008). On the other hand, the constitutional orders in Germany, Japan, and Eastern Europe appear healthy despite the fact that these documents were either imposed by foreign powers or were the result of elite-level round-table negotiations (Elster et al. 1998, Ghai \& Galli 2006, Moore \& Robinson 2004).

In perhaps the most extensive study of the question to date, Moehler (2006) provides evidence from the highly participatory Ugandan process and finds that citizens who were active in the process were no more likely to support the constitution than were other citizens. [Comparatively speaking, however, the Ugandan constitution enjoys higher levels of support than the constitutions of seven other sub-Saharan countries (Moehler 2006).] She finds that individual-level support for the constitution was influenced more by individuals' support for the National Resistance Movement regime and elite opinion than by even the respondent's own participation in the design process. This is a nuanced result, suggesting legitimacy is conditional on factors other than process, particularly the mediating factor of elite opinion as well as other aspects of the context (see also Bannon 2007). Moehler (2007) also finds that participation in constitutionmaking had downstream effects on the process, fostering attachment to democratic principles and closer monitoring of government action after the constitution-making process.

As Moehler's studies exemplify, much of the recent emphasis on constitutional design process has emanated from the conflict resolution literature (Hart 2001, 2003; Samuels 2005; Widner 2005a,b, 2007a, 2008). These authors link the successful resolution of (primarily) in- ternal conflict to episodes of constitutional design. The most comprehensive student of the question, Widner, finds a correlation between the representativeness of the main deliberative body and the level of violence five years after ratification. With popularly elected representatives, violence decreased in approximately $42 \%$ of cases and remained roughly the same in $35 \%$ of cases. Among executive-appointed bodies, the respective figures are $24 \%$ and $36 \%$.

One of the strongest theoretical claims about popular participation concerns its implications for constitutionalism - that is, a constitution's ability to constrain government. If citizens are to police the actions of government effectively, they must know with sufficient clarity what constitutes a violation of the limits of governmental power so that they can mobilize to prevent it. Constitutions help resolve this coordination problem by generating common knowledge about the scope of acceptable government behavior and by providing a focal point for citizens to organize enforcement efforts (Przeworski 1991, Weingast 1997, Carey 2000). To the extent that popular participation in a constitutional design process serves to construct focal points, it will facilitate the coordination needed to deter potential constitutional violations by government. In the most optimistic scenario, the presence of a focal point in the written text, when coupled with the more robust civil society that emerged as part of a participatory design process, will ensure that the constitution will be enforced and not serve as a mere parchment barrier (Carey 2000).

It follows logically that constitutional endurance, an important criterion of constitutional success (Voigt 2003), will be closely related to enforcement. Public involvement should enhance endurance by making enforcement more likely. Elkins et al. (2009), in a booklength study of constitutional endurance at the national level, find that public involvement in constitutional adoption, as captured in the existence of a referendum or popularly elected constitutional assembly, was positively correlated with constitutional lifespan, at least for 
democracies. For example, South Africa's celebrated 1996 document has already lasted longer than the historical mean for constitutions on the African continent. Although the world's oldest constitution (that of the United States) was not adopted by referendum, there was a relatively high level of involvement in its approval, if not its drafting. The Japanese case, it should be noted, is anomalous in this regard (Elkins et al. 2008b, Moore \& Robinson 2004).

We might also speculate on further implications of participation for constitutional design. One influential view of constitutions conceives of them as social contracts among the citizenry, designed to limit demands by the state. In this view, one would expect that more participatory processes work like supermajority rules. As the veto power of minorities increases, one might expect the adoption of more minoritarian institutions, such as judicial review (Ginsburg 2003), bicameralism, and, assuming that relevant cleavages are geographically concentrated, federalism. Supermajoritarian processes might produce supermajoritarian rules and institutional configurations, to the extent that a rule-making body will produce others in its likeness. One can also expect that the use of referenda to approve the constitution may be mimicked with direct democracy institutions in the constitution itself.

Voigt (2003) develops a set of hypotheses relating inclusive participation to substantive outcomes. He suggests that inclusive processes will lead drafters to create more independent bodies, delegating powers away from the legislature. This is a corollary, of sorts, to the prediction that the legislative model will concentrate powers in the legislature (Elster 1995; Chesterman 2005, p. 952). Voigt also believes that participatory documents will be more stable in that there will be fewer demands for renegotiation down the road and that they will be more legitimate.

We might also expect that as the power of the citizenry in design processes increases, the number and extent of constitutional rights will increase as well. The American case, in which the Bill of Rights was inserted only after public discussion and debate, makes the point quite dramatically (Arato 1995, p. 225). The Anti-Federalists wanted to include a bill of rights in the original bargain and were able to gain agreement on this during the ratification process as a condition of approval (Rakove 1997). Participation, then, begat a more extensive set of limitations on federal power. In more recent examples, we might expect that participation would be associated with positive socioeconomic rights as the constitution becomes an instrument of redistribution.

These hypotheses regarding content may be most amenable to analysis, and what evidence exists tends to support the prevailing wisdom. IDEA's survey of 12 constitutional design processes suggests that more participatory processes result in more progressive rights provisions and a higher quality of democracy (Samuels 2006). IDEA's general finding is that "more representative and inclusive constitution building processes resulted in constitutions favoring free and fair elections, greater political equality, more social justice provisions, human rights protections and stronger accountability mechanisms" (Samuels 2006, p. 668). This finding deserves further testing on a broad set of cases. Ghai (2001) has also shown that rights provisions emerging from deliberation and negotiation have more of an indigenous character and are more fervently defended and respected. Rights provisions imposed by outsiders such as former colonial masters or handed down by elites are frequently not understood or appreciated. Thus, leaders have little compunction about derogating from them.

We are able to offer some cross-national data relevant to this question, again as an effort to start the conversation rather than end it. We divide all constitution-making processes into two categories, based on whether or not they utilize a public referendum to approve the document. If Samuels's finding is generalized, it suggests that those processes involving a public referendum are more likely to have various rights provisions than those processes without a 
referendum. This is because ratification by referendum forms a downstream constraint shaping the drafting process. The IDEA results also suggest that constitutions in which the public had an approval role are more likely to involve the public in various decisions thereafter. For example, we might expect that constitutions approved by referendum would be more likely to use direct democracy devices such as the referendum in ordinary governance. We might also expect that the scope of elections would be broader.

We have gathered some descriptive data on these issues as part of the CCP (see the online data appendix at http://www. comparativeconstitutionsproject.org). The descriptive data provide partial support to the conjecture about public participation. Processes involving a referendum produce constitutions that are more likely to have virtually every category of right. Referendum constitutions also appear more likely to provide for universal suffrage, a secret ballot, a referendum process in ordinary governance, and a public role in approving constitutional amendments. We do not, however, find statistically significant differences between public referendum processes and nonreferendum processes in electing or recalling various public officials, although in most cases the direction of the difference is consistent with the predictions.

Still, it seems prudent to reserve judgment about any causal inferences with respect to these results. As with the legislative-constituent assembly analysis, because processes are themselves selected at some upstream point in constitution-making, it is likely that the association between public involvement on the one hand and rights and democracy on the other reflects the common impact of an unobserved variable. For example, a set of elites might conclude a private agreement to democratize in which constitution-making is part of the process. The elites might then seek to ensure that the process of adoption is more open and democratic, in which case both the process and result reflect a level of antecedent agreement. This problem of endogeneity is endemic in efforts to tie process to outcomes, and hence there is an important role for the careful work of case study literature to try to untangle the causal relationships.

The complement to public participation is public oversight, or the visibility of the design process. There is reason to think that transparency will have decisive effects on the manifestations of self-interest. Constitution-making typically, though not always, involves discrete moments that occur with great public fanfare. This greater visibility may reduce rent-seeking and self-interest, as interest groups seek to exploit the relative anonymity of ordinary politics (Mueller 2000). Appeals to public reason, rather than to private interest, are presumed to be prevalent during constitutional drafting. However, publicity may lead to grandstanding as political leaders seek to mobilize their own supporters (Brown 2008). Along these lines, Stasavage (2007) provides a game theoretic justification for limiting transparency, arguing that rather than generate consensus, open deliberation has the potential to lead to mass polarization.

Analyzing the French and American experiences, Elster (2000) finds that secrecy and transparency matter and that publicity explains some of the failures of the French constitutional assemblies around 1789. Secrecy, in his view, is amenable to hard bargaining, whereas publicity facilitates arguing. As a solution to this tension between transparency and secrecy, Elster (2006) employs an hourglass metaphor to describe the optimal role of the public in the process, with participation via public hearings at the upstream stage and some form of ratification possible at the downstream stage. The actual writing and deliberation (the neck of the hourglass) should be shielded from the public eye to avoid the pitfalls described above. Banting \& Simeon (1985) cite the Spanish Constitution of 1978 as mostly achieving this ideal, with small, private working groups that hammered out the final draft bookended by public scrutiny. The South African experience, in 
which public input and elite bargaining was followed by a certification process by the constitutional court, provides another innovative model. The precise need for transparency and secrecy in negotiation may depend on particular contextual circumstances.

The visibility of constitutional design also might affect the ability of certain kinds of interests to organize, particularly those groups focused on the general interest. Public interest groups that face collective action problems in ordinary politics may be more likely to organize for the relatively infrequent iterations of constitutional politics (Boudreaux \& Pritchard 1993; but see Sutter 1995, p. 129). If the profile of the participating interest groups veers toward the public good in this way, constitutional politics might indeed achieve the normative ambition of greater focus on the common good. However, there is the offsetting consideration of stakes. Private interest groups may invest more energy in playing for rules at the constitutional level precisely because of the presumptively higher stakes in the selection of rules, thus discounting the increased participation of public interest groups.

\section{CONCLUSION}

This review has explored the theoretical and empirical relationships between the process of constitutional design and constitutional outcomes. On the theoretical side, we find a broad consensus in the literature about the importance of public involvement as well as an apparent trend in practice. Yet many of the assumptions of proponents of participation remain untested, and the precise relationships between participation and desirable outcomes of interest remain underspecified.

In general, scholars have been far better at generating hypotheses relating process to outcomes than at testing them. Individual case studies have provided some insights, but large- $n$ work has been hindered by a lack of data and by a need for conceptual refinement. Fortunately, Widner and her collaborators in the CWCR project have begun to develop systematic measures of process variables, and the CCP has produced some measures of dependent variables of interest. Our own analysis utilizing these data sources suggests an association between processes that involve the public in the adoption of the constitution and the presence of rights and certain democratic institutions in the resulting document. This finding is consistent with the case study literature, although we are cautious about drawing conclusions about causality. However, we find little support for the claims about institutional self-interest on the part of legislatures that control constitutional design.

Constitutional design processes are loaded with expectations about endurance, efficacy, the resolution of conflicts, and political reconstruction (Arjomand 2007). In the real world, however, most constitutions fail (Scheppele 2008). A key normative question is whether aspects of process can be manipulated to reduce the probability of failures, but this question requires much more positive work on the complex relationships among process, content, and outcomes.

\section{DISCLOSURE STATEMENT}

The authors are not aware of any affiliations, memberships, funding, or financial holdings that might be perceived as affecting the objectivity of this review.

\section{ACKNOWLEDGMENT}

We thank Rosalind Dixon for helpful comments. 


\section{LITERATURE CITED}

Ackerman B. 1993. We the People. Cambridge, MA: Harvard Univ. Press

Albert C, Lindsay SM, Rowe LS. 1894. Supplement: Constitution of the Kingdom of Italy. Ann. Am. Acad. Polit. Soc. Sci. 5:1-44

Arangio-Ruiz G. 1895. The amendments to the Italian Constitution. Ann. Am. Acad. Polit. Soc. Sci. 6:31-57

Arato A. 1995. Forms of constitution making and theories of democracy. Cardozo Law Rev. 17:191-231

Arjomand S, ed. 2007. Constitutionalism and Political Reconstruction. Leiden: Brill

Banks A. 2008. Expanding participation in constitution making: challenges and opportunities. William Mary Law Rev. 49(4):1043-69

Bannon AL. 2007. Designing a constitution-drafting process: lessons from Kenya. Yale Law 7. 116(8):1824-72

Banting KG, Simeon R, eds. 1985. Redesigning the State: The Politics of Constitutional Change. Toronto: Univ. Toronto Press

Beard C. 1913. An Economic Interpretation of the Constitution. New York: Macmillan

Benomar J. 2004. Constitution-making after conflict: lessons for Iraq. 7. Democr. 15(2):81-109

Bentwich N. 1924. The Constitution of Egypt. F. Comp. Legis. Int. Law 6(1):41-49

Billias G, ed. 1990. American Constitutionalism Abroad. New York: Greenwood

Blaustein AP, Sigler JA, eds. 1988. Constitutions That Made History. New York: Paragon House

Boudreaux D, Pritchard AC. 1993. Rewriting the constitution: an economic analysis of the constitutional amendment process. Fordham Law Rev. 62(1):111-62

Brandt M. 2005. Constitutional Assistance in Post-Conflict Countries: The UN Experience: Cambodia, East Timor and Afghanistan. New York: United Nations

Brown NJ. 2008. Reason, interest, rationality, and passion in constitution drafting. Perspect. Polit. 6(4):675-89

Buchanan J, Tullock G. 1962. The Calculus of Consent. Ann Arbor: Univ. Mich. Press

Burnell P. 2008. The relationship of accountable governance and constitutional implementation, with reference to Africa. F. Polit. Law 1(3):10-24

Carey JM. 2000. Parchment, equilibria, and institutions. Comp. Polit. Stud. 33:735-61

Carey JM. 2007. Does it matter how a constitution is created? Presented at Exporting Democracy: What Democracies Can and Cannot Do, Univ. Texas, Austin, April 21

Chapman CE. 1925. The Cuban Constitution and Congress. Calif. Law Rev. 14(1):22-35

Chesterman S. 2005. Imposed constitutions, imposed constitutionalism, and ownership. Conn. Law Rev. $37: 947-54$

Choudhry S. 2006. The Migration of Constitutional Ideas. New York: Cambridge Univ. Press

Clark JF. 1994. The national conference as an instrument of democratization in Francophone Africa. 7. Third World Stud. 11:304-335

Clark RT. 1921. The constitution of Esthonia. 7. Comp. Legis. Int. Law 3(4):245-50

Congleton R. 2003. Improving Democracy through Constitutional Reform: Some Swedish Lessons. Boston: Kluwer Acad.

Currier CFA. 1893. Supplement: constitutional and organic laws of France. Ann. Am. Acad. Polit. Soc. Sci. $3: 1-77$

Davidson NG. 1925. The Constitution of Iraq. 7. Comp. Legis. Int. Law 7(1):41-52

Davis DM. 2003. Constitutional borrowing: the South Africa experience. Int. F. Const. Law 1(2):181-95

Dedek V. 1921. The constitution of Czecho-Slovakia. 7. Comp. Legis. Int. Law 3(1):115-22

Ebrahim H, Fayemi K, Loomis S. 1999. Promoting a Culture of Constitutionalism and Democracy in Africa. Recommendations to the Commonwealth Heads of Government. New Delhi: Commonwealth Human Rights Initiative. http://www.humanrightsinitiative.org/publications/const/ constitutionalism_booklet_1999.pdf

Ehindero SG. 1991. The Constitutional Development of Nigeria 1849-1989. Nigeria: Ehindero

Elkins Z. 2003. Designed by diffusion: international networks and the spread of democracy. PhD Diss., Dep. Polit. Sci., Univ. Calif., Berkeley

Elkins Z. 2009. Constitutional networks. In Networked Politics: Agency, Power, and Governance, ed. M Kahler, pp. 43-66. Ithaca, NY: Cornell Univ. Press 
Elkins Z, Ginsburg T. 2007. The Comparative Constitutions Project. http://www. comparativeconstitutionsproject.org

Elkins Z, Ginsburg T, Blount J. 2008a. Citizen as founder: participation in constitutional design. Temple Law Rev. In press

Elkins Z, Ginsburg T, Melton J. 2008b. Baghdad, Tokyo, Kabul . . . ? Constitution-making in occupied states. William Mary Law Rev. 49:1139-78

Elkins Z, Ginsburg T, Melton J. 2009. The Lifespan of Written Constitutions. New York: Cambridge Univ. Press. In press

Elster J. 1995. Forces and mechanisms in the constitution-making process. Duke Law 7. 45:364-96

Elster J. 1996. The role of institutional interest in East European constitution-making-explaining legislative dominance. East Eur. Const. Rev. 5(6):63-65

Elster J. 1997. Ways of constitution-making. Democracy's Victory and Crisis, ed. A Hadenius, pp. $123-42$. Cambridge, UK: Cambridge Univ. Press

Elster J. 2000. Arguing and bargaining in two constituent assemblies. Univ. Pa. F. Const. Law 2:345-421

Elster J. 2006. Legislatures as constituent assemblies. In The Least Examined Branch: The Role of Legislatures in the Constitutional State, ed. RW Bauman, T Kahana, pp. 181-97. Cambridge, UK: Cambridge Univ. Press

Elster J, Offe C, Preuss U. 1998. Institutional Design in Post-Communist Societies: Rebuilding the Ship at Sea. Cambridge, UK/New York: Cambridge Univ. Press

Feldman N. 2005. Imposed constitutionalism. Conn. Law Rev. 37:857

Fish MS. 2006. Stronger legislatures, stronger democracy. 7. Democr. 17(1):5-20

Fish MS, Kroenig M. 2009. The Handbook of National Legislatures: A Global Survey. New York: Cambridge Univ. Press

Friedman B, Saunders C, eds. 2003. International fournal of Constitutional Law. Symposium Issue: Constitutional Borrowing, 1:177-324. http://icon.oxfordjournals.org/content/vol1/issue2/index.dtl

Ghai Y. 2001. Human Rights and Social Development: Toward Democratization and Social Fustice. Geneva: UNRISD

Ghai Y. 2004. The constitution reform process: comparative perspectives. Presented at Toward Inclusive and Participatory Constitution Making Conf., Kathmandu, Nepal, Aug. 3-5. http://www.idea.int/news/ upload/Nepal\%20-\%20workshop\%20paper\%20-\%20Yash\%20Ghai.pdf

Ghai Y. 2005. A journey around constitutions: reflecting on contemporary constitutions. South Afr. Law 7 . 122:804-31

Ghai Y, Galli G. 2006. Constitution building processes and democratization. In Democracy, Conflict, and Human Security: Further Readings. Stockholm: IDEA

Ghai Y, Lattimer M, Said Y. 2003. Building Democracy in Iraq. London: Minority Rights Group Int. http:// www.minorityrights.org/download.php?id=109

Ginsburg T. 2003. Fudicial Review in New Democracies: Constitutional Courts in Asian Cases. New York: Cambridge Univ. Press

Go J. 2003. A globalizing constitutionalism. Int. Sociol. 18:71-95

Golay JF. 1958. The Founding of the Federal Republic of Germany. Chicago: Univ. Chicago Press

Goldwin RA, Kaufman A, eds. 1988. Constitution Makers on Constitution Making: The Experience of Eight Nations. Washington, DC: Am Enterp. Inst. Public Policy Res.

Goldwin RA, Kaufman A, Schambra WA, eds. 1989. Forging Unity Out of Diversity: The Approaches of Eight Nations. Washington, DC: AEI Press

Hart HLA. 1961. The Concept of Law. Oxford: Oxford Univ. Press

Hart V. 2001. Constitution-making and the transformation of conflict. Peace Change 26(2):153-76

Hart V. 2003. Democratic constitution making. Sp. Rep. 107, U.S. Inst. Peace, Washington, DC. http://www. usip.org/pubs/specialreports/sr107.html

Haysom N. 2004. Lessons from the South African transition. Presented at Toward Inclusive and Participatory Constitution Making, Aug. 3-5, Kathmandu, Nepal

Horowitz DL. 2002. Constitutional design: proposals versus processes. See Reynolds 2002, pp. 15-36

Huq A. 2009. The story of Hamid Karzai: the paradoxes of state-building and human rights. In Human Rights Advocacy Stories, ed. D Hurwitz, M Satterthwaite, D Ford, pp. 505-34. Eagan, MN: Thomson/West 
Hyden G, Venter D, eds. 2001. Constitution-Making and Democratisation in Africa. Pretoria: Africa Inst. South Africa

Kantorowicz H. 1927. The New German constitution in theory and practice. Economica 19:37-62

Kelsen H. 1945 (1961). General Theory of Law and State, transl. A. Wedberg. New York: Russell \& Russell

Keogh D, McCarthy AJ. 2007. The Making of the Irish Constitution. Cork: Mercier

Kuhonta EM. 2008. The paradox of Thailand's 1997 "People's Constitution": Be careful what you wish for. Asian Survey 48(3):373-92

McGuire R, Ohsfeldt R. 1986. An economic model of voting behavior: the ratification of the United States Constitution. 7. Econ. Hist. 46(1):79-111

McGuire R, Ohsfeldt R. 1989a. Public choice analysis and the ratification of the Constitution. In The Federalist Papers and the New Institutionalism, ed. B Grofman, D Wittman, pp. 175-204. New York: Agathon

McGuire R, Ohsfeldt R. 1989b. Self-interest, agency theory, and political voting behavior: the ratification of the United States Constitution. Am. Econ. Rev. 79(1):219-34

Meyer JW, Boli J, Thomas G, Ramirez FO. 1987. Institutional Structure: Constituting State, Society and the Individual. Newbury Park, CA: Sage

Moehler D. 2006. Public participation and support for the constitution in Uganda. F. Mod. Afr. Stud. 44(2):275308

Moehler D. 2007. Distrusting Democrats: Outcomes of Participatory Constitution-Making. Ann Arbor: Univ. Mich. Press

Moore RA, Robinson DL. 2004. Partners for Democracy: Crafting the New Fapanese State Under MacArthur. New York: Oxford Univ. Press

Morse HB. 1919. The new constitution of China. 7. Comp. Legis. Int. Law 1(3):183-95

Moses B. 1893. Supplement: Constitution of the Republic of Colombia. Ann. Am. Acad. Polit. Soc. Sci. 3:1-70

Mueller D. 2000. Constitutional Democracy. New York: Oxford Univ. Press

Murphy WF. 2007. Constitutional Democracy: Creating and Maintaining a fust Political Order. Johns Hopkins Series in Constitutional Thought, ed. S Levinson, JK Tulis. Baltimore, MD: Johns Hopkins Univ. Press

Onyango D. 2004. Ghai: Why I would not accept to chair review again. East Afr. Stand. (Nairobi), Mar. 28, p. 15. http://allafrica.com/stories/printable/200403290312.html

Perry B. 1992. Constitutional Johnny Appleseeds: American consultants and the drafting of foreign constitutions. Albany Law Rev. 55:767-92

Pollock JK Jr. 1923. The constitution of Latvia. Am. Polit. Sci. Rev. 17(3):446-48

Proksch SO. 2007. Ideology and the politics of constitution making: the institutional organization of the European convention. Presented at 10th Biennial Conf. Eur. Union Stud. Assoc., May 17-19, Montreal

Przeworski A. 1991. Democracy and the Market. New York: Cambridge Univ. Press

Quigley HS. 1924. The constitution of China. Am. Polit. Sci. Rev. 18(2):346-50

Rakove J. 1997. Original Meanings: Politics and Ideas in the Making of the Constitution. New York: Vintage

Reynolds A, ed. 2002. The Architecture of Democracy. New York: Oxford Univ. Press

Rubin BR. 2004. Crafting a constitution for Afghanistan. 7. Democracy 15(3):5-19

Russell P. 1993. Constitutional Odyssey: Can Canadians Become a Sovereign People? Toronto: Univ. Toronto Press Saleilles R. 1895. The development of the present constitution of France. Ann. Am. Acad. Polit. Soc. Sci. 6:1-78 Samuels K. 2005. Post-conflict peace-building and constitution-making. Chicago 7. Int. Law 6(2):663-82

Samuels K. 2006. Constitution Building Processes and Democratization: A Discussion of Twelve Case Studies. Geneva: IDEA

Samuels K, Wyeth VH. 2006. State-Building and Constitutional Design After Conflict. New York: Int. Peace Acad.

Scheppele K. 2008. A constitution between past and future. William Mary Law Rev. 49(4):1377-407

Selassie BH. 2003. The Making of the Eritrean Constitution: The Dialectic of Process and Substance. Trenton, NJ: Red Sea Press

Smith S, Remington T. 2001. The Politics of Institutional Choice: The Formation of the Russian State Duma. Princeton, NJ: Princeton Univ. Press

Stasavage D. 2007. Polarization and publicity: rethinking the benefits of deliberative democracy. F. Polit. 69(1):59-72 
Sunstein CR. 2001. Designing Democracy: What Constitutions Do. Oxford: Oxford Univ. Press

Sutter D. 1995. Constitutional politics within the interest-group model. Const. Polit. Econ. 6(2):127-37

Texas Law Rev. 2004. Symposium: Comparative Avenues in Constitutional Law. 82:1653-737. http://www. utexas.edu/law/journals/tlr/abstracts/82/82-7.pdf

Tsebelis G. 2002. Veto Players: How Political Institutions Work. Princeton, NJ: Princeton Univ. Press

Tsebelis G, Proksch SO. 2007. The art of political manipulation in the European convention. F. Common Mark. Stud. 45(1):157-86

Voigt S. 2003. The consequences of popular participation in constitutional choice-toward a comparative analysis. In Deliberation and Decision, ed. A van Aaken, C List, C Luetge, pp. 199-229. Aldershot, UK: Ashgate

Weingast BR. 1997. The political foundations of democracy and the rule of law. Am. Polit. Sci. Rev. 91(2):24563

Widner J. 2005a. Constitution Writing and Conflict Resolution. Helsinki: UN Univ. World Inst. Dev. Econ. Res.

Widner J. 2005b. Constitution writing \& conflict resolution: data \& summaries. Accessed Dec. 17, 2008. http://www.princeton.edu/ pcwcr/index.html

Widner J. 2007a. The effects of constitution writing procedures on choice of terms \& patterns of violence: some data, some observations, and many reasons for modesty. Presented at Stanford Workshop Comp. Polit., Jan. 22, Palo Alto, CA

Widner J. 2007b. Proceedings "Workshop on Constitution Building Processes," Princeton University, May 1720. Princeton, NJ: Bobst Cent. Peace Justice, Princeton Univ., Interpeace Int. IDEA. http://www. princeton.edu/bobst/docs/Constitutions_Edited_Proceedings_1_(2).doc

Widner J. 2008. Constitution writing in post-conflict settings: an overview. William Mary Law Rev. 49(4):151341 